\title{
Review
}

Neuro[mmunoModulation

\section{Neuroimmune Alterations in Autism: A Translational Analysis Focusing on the Animal Model of Autism Induced by Prenatal Exposure to Valproic Acid}

\author{
Iohanna Deckmann ${ }^{a-c}$ Gustavo Brum Schwingel ${ }^{a-c} \quad$ Mellanie Fontes-Dutra ${ }^{a-c}$ \\ Victorio Bambini-Junior ${ }^{\mathrm{a}, \mathrm{c}, \mathrm{d}}$ Carmem Gottfried ${ }^{\mathrm{a}-\mathrm{c}}$ \\ aTranslational Research Group in Autism Spectrum Disorders-GETTEA, Universidade Federal do Rio Grande \\ do Sul (UFRGS), Porto Alegre, Brazil; ${ }^{b}$ Neuroglial Plasticity Group, Department of Biochemistry, Universidade \\ Federal do Rio Grande do Sul (UFRGS), Porto Alegre, Brazil; ' National Institute of Science and Technology on \\ Neuroimmunomodulation (INCT-NIM), Rio de Janeiro, Brazil; ${ }^{\mathrm{d}}$ School of Pharmacology and Biomedical Sciences, \\ University of Central Lancashire, Preston, UK
}

\section{Keywords}

Autism spectrum disorder · Neuroimmune alterations ·

Cytokines · Animal model · Valproic acid

\begin{abstract}
Autism spectrum disorder (ASD) is a highly prevalent developmental disorder characterized by deficits in communication and social interaction and in stereotyped or repetitive behaviors. Besides the classical behavioral dyad, several comorbidities are frequently present in patients with ASD, such as anxiety, epilepsy, sleep disturbances, and gastrointestinal tract dysfunction. Although the etiology of ASD remains unclear, there is supporting evidence for the involvement of both genetic and environmental factors. Valproic acid (VPA) is an anticonvulsant and mood stabilizer that, when used during the gestational period, increases the risk of ASD in the offspring. The animal model of autism induced by prenatal exposure to VPA demonstrates important structural and behavioral features that can be observed in individuals with
\end{abstract}

() 2018 S. Karger AG, Basel

E-Mail karger@karger.com www.karger.com/nim autism; it is thus an excellent tool for testing new drug targets and developing novel behavioral and drug therapies. In addition, immunological alterations during pregnancy could affect the developing embryo because immune molecules can pass through the placental barrier. In fact, exposure to pathogens during the pregnancy is a known risk factor for ASD, and maternal immune activation can lead to autisticlike features in animals. Interestingly, neuroimmune alterations are common in both autistic individuals and in animal models of ASD. We summarize here the important alterations in inflammatory markers, such as cytokines and chemokines, in patients with ASD and in the VPA animal model.

(c) 2018 S. Karger AG, Basel

\section{Introduction}

Since the first descriptions in the early 1940s, new data has been shared to the scientific community about autism spectrum disorder (ASD) [1]. Currently, ASD is diag- 
nosed by changes in 2 behavioral domains: (a) communication and social interaction impairments in multiple contexts, including deficits in social reciprocity and nonverbal communication used for social interaction and in skills to initiate, maintain, and understand relationships; and (b) Repetitive behaviors, and restricted and stereotyped activities [2].

There is no clinical marker or quantitative examination in peripheral tissues that can be used for an early diagnosis of this disorder [3]. Even though there are many well-accepted surveys for behavioral diagnosis, ASD is a highly complex and heterogeneous disorder, presenting distinct manifestations, with no two individuals sharing the same set of symptoms $[4,5]$. The large heterogeneity of the symptoms could potentially be explained by individual differences, for example in the immune system. Alterations in cytokine levels are common in autistic individuals, with a frequent observation of elevated levels of proinflammatory cytokines $[6,7]$.

Genome-wide association studies (GWAS) have already described interesting relations between immune system disruptions and neurological disorders like autism and schizophrenia [8]. Specifically, in ASD, an interesting example is the dysregulated genes reported, i.e., IL$1 \beta$ and IL-12, both involved in cytokine-cytokine receptor interaction [9]. One study relating ASD and neuroimmune genetic disruption shows an alteration in glutamate receptor metabotropic 5 (GRM5) single-nucleotide polymorphisms (SNPs) [10]. This is not exactly a neuroimmunological alteration, but this gene is highly expressed in many neuronal regions implicated in ASD, besides acting on synaptic plasticity, modulating innate immunity, and microglia activation. When GRM5-positive allosteric modulation occurs, several negative behaviors described in ASD are rescued, including stereotypy [10]. Evidence of an intersection of gene interactions and ASD diagnosis demonstrates the importance of the genetic contribution to the neuroimmunological imbalance in ASD.

According to the most recent epidemiological survey conducted in the USA, the current incidence of ASD is 1:68 [11]. Although the etiology of ASD remains unknown, it is hypothesized that the onset of this disorder depends on the interplay between genetic and environmental factors. Epidemiological observations suggest that exposure to teratogens, especially in the first trimester of pregnancy, could be closely related to ASD development. An important example is the prenatal exposure to valproic acid (VPA) $[12,13]$.

\section{VPA and the VPA Animal Model}

The compound VPA is a drug widely used as an anticonvulsant and mood stabilizer in the treatment of epilepsy and bipolar disorder $[13,14]$. Although VPA is well tolerated and safe in adults, there is evidence of its teratogenicity [14]. Clinical studies over the years have shown that intrauterine exposure to VPA is associated with birth defects, cognitive impairments, and an increased risk of autism [13]. In recent years, animal studies have investigated the anatomical, behavioral, molecular, immunological, and physiological outcomes related to exposure to VPA [13].

Epidemiological observations demonstrate a strong correlation between prenatal exposure to VPA and ASD [15-18]. Based on these observations, an animal model for the study of autism prenatally induced by VPA was established [19-21]. Behavioral studies show that exposure to VPA in rats and mice leads to several autistic-like behaviors in male offspring, including social behavior deficits, increased repetitive behaviors, and communication deficits similar to those found in ASD subjects [19-23]. This points to the animal model being translational, as the diagnosis of ASD is given through behavioral evaluation.

Since the current diagnostic criteria for ASD are exclusively clinical and are the result of behavioral analyses, the study of ASD in humans prior to the onset of symptoms becomes a very challenging task. Animal models provide the opportunity for analyzing the developmental changes that can trigger ASD-like features [24, 25]. They provide the possibility to study and manipulate biological pathways for understanding, and even preventing or reversing, the appearance of the morphological, functional, and behavioral alterations found in ASD. Studies on animals can also reveal some new important factors involved in the etiology of this disorder.

\section{Histone-Deacetylases Inhibitors and Neuroimmune Alterations}

Autism and many other psychiatric disorders, like schizophrenia, bipolar disorder, and major depression, present not only susceptibility to environmental risk factors, but also a high genetic influence [26, 27]. In the last years, there is growing evidence indicating that epigenetic alterations may have an important role in several psychiatric disorders.

Epigenetic regulation includes long-term changes, like DNA methylation, and short-term changes, like modifications in the histone proteins associated with DNA [28]. Histones are small basic proteins that act as spools around
Deckmann/Schwingel/Fontes-Dutra/ Bambini-Junior/Gottfried 
which DNA winds, regulating the packaging of DNA and allowing or inhibiting gene expression. When the histone is acetylated by histone acetyltransferases, this local alteration leads to chromatin decondensation, promoting gene expression by the activation of the transcription machinery. On the other hand, histone deacetylation, mediated by histone deacetylases (HDACs), results in the inhibition of transcription, promoting a controlled gene expression $[28,29]$.

Substantial epigenetic alterations have been found in the regulatory regions of many candidate genes for ASD, such as the GABAergic genes, GAD67, Reelin, oxytocin receptor, and $B D N F$, showing that the epigenetic component in ASD has been widely studied [26]. Histone posttranslational modifications, like acetylation and methylation, play a key role in the regulation of gene expression [30]. These characteristics are crucial for important biological processes like the actions of immune system, in which HDACs modulate the gene expression of toll-like receptors (TLRs) and interferon (IFN) signaling pathways [31].

The HDAC inhibitor drugs play an important role in the immune context. Studies show increased transcription of the major histocompatibility complex (MHC) class II, located in the tumor cell surface in mouse and humans [32], indicating an interesting effect on several immune cells. It leads to less viability of T CD4 cells and decreases the production of proinflammatory cytokines, making the T CD8 cells increase the secretion of proinflammatory cytokines, modulating the activity of natural killer (NK) cells and regulatory T cells [33].

Hence, several drugs used as antidepressants and mood stabilizer are characterized as HDAC inhibitors. Valproate, a well-known HDAC inhibitor drug, induces important delays in neuronal maturation [34], already described in ASD [35]. Moreover, VPA prenatal exposure alters the postnatal histone 3 (H3) acetylation levels in the cerebellum [36], stimulates glial cell proliferation in the developing rat brain [37], and also induces changes in acetylation levels in the astrocytes of the hippocampus and cortex in cell culture more than other antidepressants and mood stabilizers do [38]. These unique effects of VPA, especially in comparison to similar HDAC inhibitor drugs, indicate that the VPA molecule might have exclusive properties which are still unclear, although some evidence indicates a possible VPA binding in the catalytic center of HDACs [39]. Those epigenetics alterations occur before the well-described neuroimmune alterations, and may therefore be involved in the immune disturbances [36]. These data highlight the role of VPA and

Neuroimmune Alterations in Autism

Focusing on the VPA Model
HDAC inhibitors as epigenetic modulators, which could be underpinning the immunological alterations as well as the neurological outcomes in psychiatric disorders.

\section{The Intimate Relationship between the Central Nervous System and Immune System}

For a long time, the immune system and the central nervous system (CNS) were considered compartments that operate separately and independently. However, recent studies demonstrate an active communication between these two systems, whereby they modulate each other "bi-directly" with neurotransmitters and neuromodulators in the periphery. In addition, in a landmark study, lymphatic vessels were discovered in the CNS, putting in check the current view of the brain as an "immune privileged site" and raising new possibilities for the crosstalk between the brain and the immune system [40]. Anatomically, the CNS is bathed by the cerebrospinal fluid (CSF), and surrounded by the meninges which contain lymphatic and blood vessels [41]. The brain parenchyma is separated from the circulating blood by a blood-brain barrier (BBB) which prevents the entry of pathogens, circulating immune cells, and other substances from the blood.

The $\mathrm{BBB}$ is defined as a semipermeable membrane that separates the circulating blood from the brain and extracellular fluid in the CNS [42]. CNS blood vessels interact with different peripheral and brain-resident immune cell populations, like perivascular macrophages and microglial cells, respectively. The BBB is formed by the concerted action of endothelial and glial cells. During development, at embryonic day 10 (E10), initial clues for angiogenesis lead to the early properties of $\mathrm{BBB}$ in the CNS by activation of the $\mathrm{Wnt} / \beta$-catenin canonical pathway [43$45]$. There is no consensus about exactly when the BBB is fully formed [46]. Nevertheless, at E15, pericytes, which play a crucial role in BBB formation and maintenance, begin to interact intimately with endothelial cells (EC) in the capillary walls [47]. In postnatal life, EC of brain capillaries are covered up by mature pericytes, sharing their basement membrane with the endothelium [48]. Moreover, the astrocytes project cellular terminations called "end feet" toward the capillaries, providing the outer layer of the BBB. Pericytes and astrocytes also secrete proteins involved in extracellular matrix formation and deposition of the basement membrane $[48,49]$.

The presence of this limiting barrier allows the CNS to control and fine-tune the flow of a variety of molecules 
from the periphery, regulating its permeability to seek homeostasis. In CNS physiology, there are extensive vessels where monocytes, granulocytes, and dendritic cells (DC) circulate [50]. In addition, the brain parenchyma is populated with microglia, resident cells from the immune lineage that play a crucial role in brain surveillance and response against multiple types of damage. Studies on rodents show that, during neurodevelopment, specific monocytes emerge at E7 and infiltrate the CNS at E9.5 as premacrophages, expressing the chemotactic factor CX3C chemokine-receptor 1 (CRXCR1) [50]. The presence of cytokines like interleukin (IL)- $1 \beta$ and tumor growth factor (TGF)- $\beta$ allows the differentiation of premacrophages in early microglia at E14.5, which then generate mature microglia at P14. In fact, TGF- $\beta$ seems to be crucial for microglial specification in the CNS $[51,52]$.

Microglial cells are capable of interacting with almost all cell types in the CNS, modulating cell maturation during development and promoting tissue repair and homeostasis. Moreover, in postnatal life, microglia play a crucial role in sensing perturbations in the encephalic environment, actively responding to even minor pathological changes in the CNS $[53,54]$ by altering their shape and gene expression profile. The term "microglial activation" has been considered as a shift from a "resting" to an "activated" state when a disturbance in tissue homeostasis is detected or upon experimental stimulation. However, this term implies the understanding of an "inactivated" phenotype when the brain tissue is not facing any changes in homeostasis. In fact, microglial cells are never inactive and show highly dynamic surveillance functions in the CNS $[50,55,56]$. Many authors suggest this surveillance state of the microglial cells be renamed "surveying microglia" instead of "resting microglia" [50]. These cells can shift from their "surveying" or "resting" state to "activated" or "alerted" state when facing chances in CNS homeostasis, like infections recognized by TLRs [57], cell damage, or trauma.

Recent studies have demonstrated that lipopolysaccharide (LPS) exposure downregulates the transcription factor Sal-like protein 1 (SALL1) and promotes several alterations in microglial identity, with a concomitant upregulation of genes associated with other resident macrophages, indicating that SALL1 might be important for the maintenance of microglial identity in response to immune challenge [50, 58]. Once activated, microglial cells can commit to different "reactive" phenotypes which have a large functional and molecular diversity. These changes in microglia profile are correlated with the type of challenge faced by the CNS. They can shift to a proin- flammatory state, also called the "M1 phenotype" [59], presenting highly phagocytic and neurotoxic activities and releasing proinflammatory chemokines and cytokines in response to an immune challenge, such as a microorganism invasion [60], or the presence of proinflammatory signals [61-63]. Once the immune stimulator is controlled, microglial cells are able to shift to a more neuroprotective profile called the "M2 phenotype" which involves anti-inflammatory responses $[59,64]$. Nonetheless, the activated proinflammatory profile can progress in pathological conditions. Although the immune challenge and the brain environment are responsible for the early microglial responses, signals from CNS resident and infiltrating immune cells can shape the reactive profiles of microglial cells and play an important role in many brain diseases [65-69]. All these stimuli could direct the fate of the microglia to alternative states, including microglial cell death, but information remains scarce as to the course of microglial activation, their reversibility to the surveying state [70], or the preservation of the molecular memory of previous stimuli. Moreover, cells that infiltrate from the blood and differentiate into microglia could also return to the periphery $[65,71]$.

There is a low basal entry of immune cells from the blood periphery into the CNS under normal conditions. Studies have shown that, although microglial cells play a major role in brain surveillance, perivascular macrophages represent a crucial immune regulator and sensor of perturbations in the CNS and periphery. These cells are derived from the bone marrow and are intimately associated with the bloodstream since they reside between EC and astrocyte end feet [72-74]. This privileged location of the perivascular macrophages allows them to simultaneously monitor the blood and the brain interstitial fluid, providing a fine control of brain homeostasis and $\mathrm{BBB}$ integrity $[72,75]$.

Macrophages are to be found at different locations, and they can perform specific roles in these microenvironments. In addition to the perivascular space, they are located within the choroid plexus and meningeal space. In the choroid plexus, which is considered the major site of CNS immune surveillance, there are tissue-resident macrophages called epiplexus cells residing alongside the fourth ventricle with DC, monocytes, and mast cells [76, 77]. Referred to by many authors as the "immune regulatory gate," the choroid plexus is able to induce specific immune responses and allows cell migration between the blood and CSF [78, 79].

The meningeal macrophages are positioned in the subdural meninges and act as sentinel cells for the dam- 
age and infection of brain tissue, by surveying the CSF and the extracellular lumen of meningeal blood vessels $[80,81]$. Thus, macrophages play critical roles in CNS surveillance, homeostasis, and disease.

Nonetheless, there is a variety of other immune cell types in the brain environment. In the physiological condition, studies have observed the presence of monocytes in meningeal spaces, although more evidence is still needed [82]. Granulocytes (i.e., neutrophils, mast cells, eosinophils, and basophils) can be found in meningeal spaces with mast cells also present in brain parenchyma $[72,83]$. These cells are highly phagocytic and play important roles in response to brain infections and tissue damage $[72,84$, 85]. DC, the main antigen-presenting cells in the periphery, can also be found in the CNS. They are located in the choroid plexus, meningeal space, and are especially abundant in lymphatic vessels in meninges [86-88]. The presence around these vessels suggests important roles for DC in inflammatory diseases and brain infections [40].

Under inflammatory conditions, there is extensive infiltration of immune cells into the CNS. The barriers that regulate cellular entry are the $\mathrm{BBB}$ within the CNS parenchyma and the blood-CSF barrier within the choroid plexus [89]. When brain homeostasis is compromised, immune cells can infiltrate from the periphery to the brain parenchyma due to the elevation in BBB permeability. This is generally observed and investigated in the context of a pathological CNS inflammatory response [90-92].

Under pathological conditions, microglia activation can lead to BBB disruption, allowing a substantial infiltration and amplifying the inflammatory response $[93,94]$. One of the key mediators in these processes is the release of cytokines and chemokines by the periphery and brainresident immune cells. This novel view of the immune system as an active player in brain function is modifying our current view of neuropsychiatric disorders. Immune alterations are now seen as central to the pathophysiology of many brain diseases, and a greater understanding of this neuroimmune axis will result in new therapies and diagnostic tools.

\section{Neuroimmune Alterations in ASD: From Patients to the VPA Animal Model}

In the last decade, the immune system has caught the attention of neuroscientists for the interplay between neurons and immune mediators, not only in disease, but also in the homeostasis of the brain. In the past, the CNS was called "an immune-privileged region" with the BBB controlling the crosstalk between the brain and the periphery. However, recent findings demonstrated that this privilege is not related to the absence of immune modulation in brain activity and homeostasis, but rather a timedependent specific modulation in many regions during brain development [95].

Immune cells and immune molecules, such as cytokines and chemokines, can modulate cognitive, emotional, and behavioral processes, triggering different responses in neuronal and glial cells [96]. Cytokines are small signaling molecules that act as mediators of communication between immune cells. Their roles include the stimulation and regulation of cell development, maturation, and the response to immune challenges $[97,98]$. Chemokines can be characterized as a vast group of 8 - to $10-\mathrm{kDa}$ molecules from the superfamily of cytokines, that induce the chemotaxis of immune cells. Once bound in their receptor, the complex chemokine-receptor can activate signaling cascades that induce immune cell-trafficking to the target area. This complex is also important as a molecular signal in the crosstalk among neuronal and glial cells and immune resident cells in the nervous system (e.g., microglia) $[99,100]$. Since chemokines have the capacity to target different types of receptor, they can modulate different cell processes, including cell adhesion and proliferation, phagocytosis, apoptosis, angiogenesis, cytokine secretion, and T cell activation [101].

Lymphocytes are cells capable of recognizing any foreign antigens displayed by antigen-presenting cells, thereby constituting the main cells of adaptive immunity [102]. Lymphocytes respond by proliferating and differentiating in effector cells, whose function is the elimination of the pathogen and the creation of an immunological memory [103]. When naïve $\mathrm{CD} 4+\mathrm{T}$ cells encounter specific antigens, they can differentiate into a range of effector subgroups. Several transcription factors are individually required for $\mathrm{T}$ cell differentiation, generating a specific lineage that expresses characteristic cytokines. So, once the transcription factors are activated, they promote the differentiation of naive $\mathrm{T}$ cells, which then differentiate, according to specific immunological responses, into T helper (Th)1, Th2, and Th17 cells. In the presence of IFN- $\gamma$ and IL-12, signal transducer and activator of transcription (STAT) 1 and STAT4 signal the expression of the transcription factor $\mathrm{T}$ box expressed in $\mathrm{T}$ cells (T-bet), promoting a Th1 response. On the other hand, Th2 cell commitment occurs when IL-4 and STAT6 increase the expression of GATA-binding protein 3 (GATA3) transcription factor. The presence of TGF- $\beta$ as- 


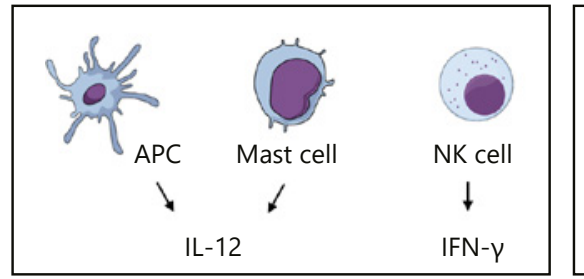

$\downarrow$

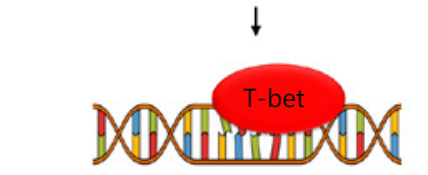

$\downarrow$
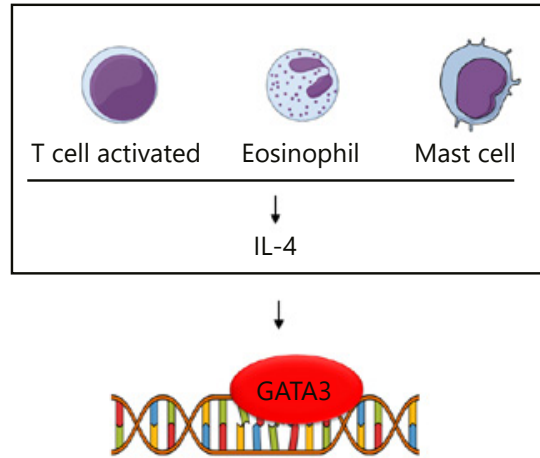
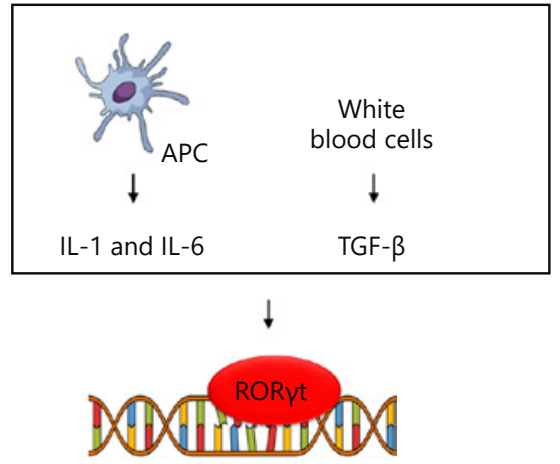

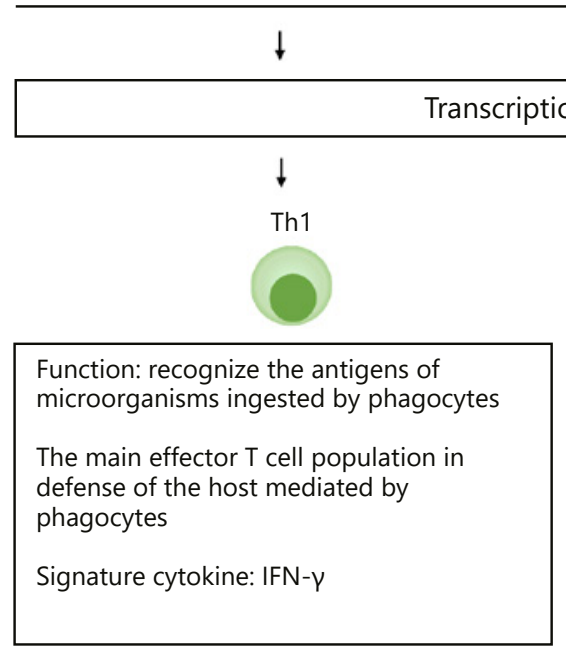

$\downarrow$

$\downarrow$

Function: recognize antigens produced by helminths and other microorganisms, as well as antigens associated with allergies

It is a mediator of the independent defense of phagocytes. Eosinophils and mast cells have central pappers

Signature cytokines: IL-4, IL-5, and IL-13
Function: stimulate neutrophil rich inflammatory responses to eradicate extracellular bacteria and fungi

Also important as mediators of tissue damage in autoimmune diseases

Signature cytokines: IL-17 and IL-22

Fig. 1. Th1, Th2, and Th17 commitment lineages from naïve CD4+ T cells. The main functions of each immune response and the signature cytokine are highlighted in the boxes. APC, antigen-presenting cell; NK, natural killer cell; T-bet, T box expressed in T cells; GATA3, GATA-binding protein 3; ROR $\gamma$ t, a retinoid-related orphan receptor $\gamma$ isoform; IL, interleukin; IFN, interferon; TGF, transforming growth factor.

sociated with IL-6 signaling via STAT3, generates the expression of a retinoid-related orphan receptor $\gamma$ isoform (ROR $\gamma \mathrm{t}$ ) transcription factor, resulting in the differentiation of Th17 cells. TGF- $\beta$ associated with IL- 2 signaling via STAT5, is known to generate, at least in vitro, inducible regulatory $\mathrm{T}$ cells which express Foxp 3 transcription factor (Fig. 1) [104].

The modulation of cytokine levels can significantly alter brain physiology and also behavior. Recent studies highlight a link between immune dysfunction and behavioral impairments [105]. For example, the relation between IL- 6 and several altered behaviors has already been established in the literature [106-108]. Signs of neuroinflammation and altered inflammatory responses are seen in ASD subjects throughout life [109]. Therefore, some authors hypothesize that the neuroimmune disturbances could be causal for ASD [110]. Below, we provide the details of the main neuroimmunological findings (Tables 1 , 2 ) in ASD subjects and the VPA animal model of autism.

\section{Interleukin $1 \beta$}

IL- $1 \beta$ is a cytokine produced by fibroblasts, monocytes, tissue macrophages, DC, B lymphocytes, epithelial cells, and NK cells [111], that promotes inflammation by indirectly stimulating lymphocyte function and activating macrophages $[112,113]$. IL- $1 \beta$ has the ability to increase the expression of adhesion molecules such as VCAM-1 and ICAM-1, supporting the infiltration of inflammatory cells from the circulation into the tissue, and resulting in chronic IL-1-induced inflammation [112, 
Table 1. Main cytokines with altered levels in autism subjects

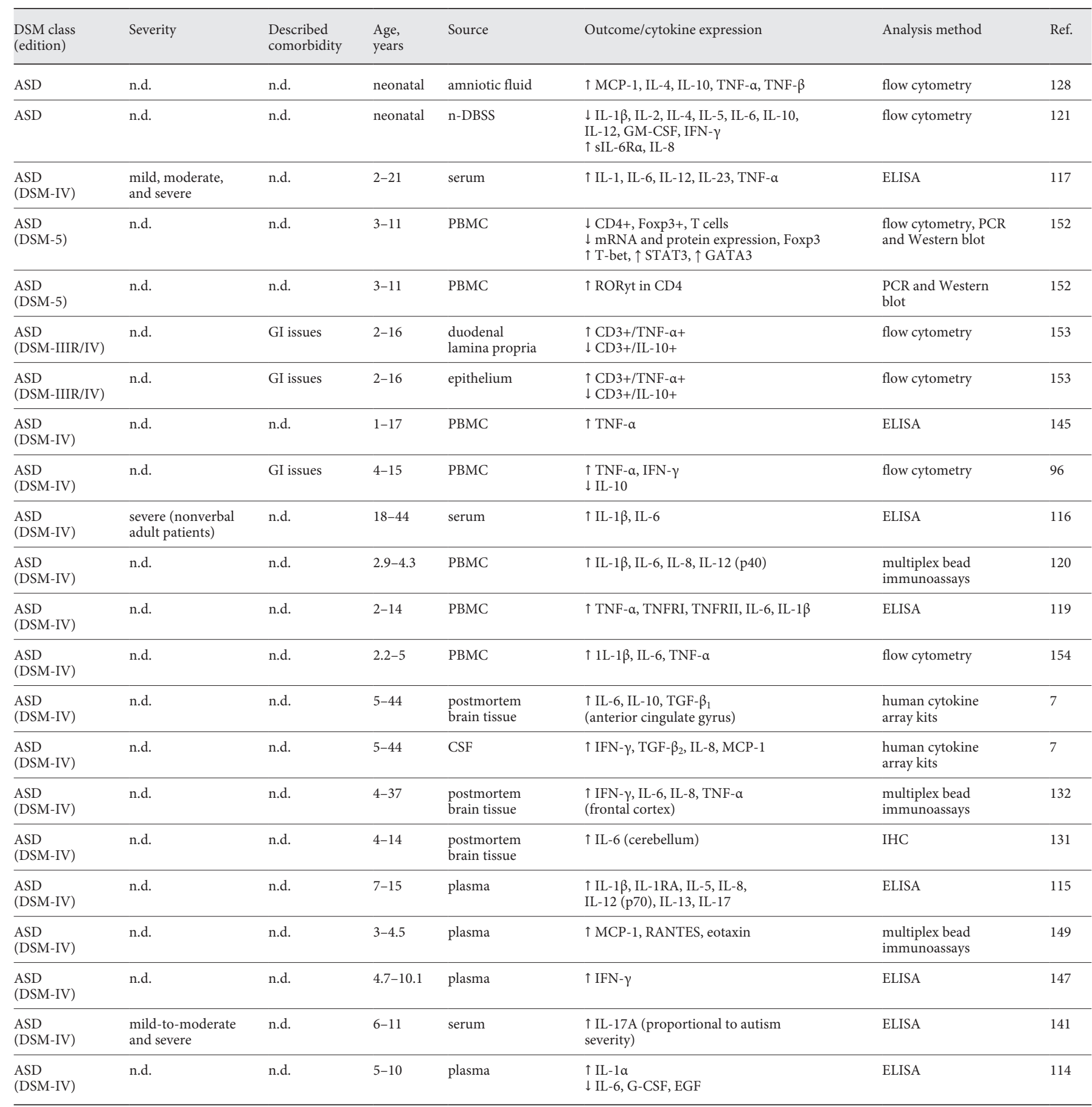

ASD, autism spectrum disorder; DSM, Diagnostic and Statistical Manual of Mental Disorders; CSF, cerebrospinal fluid; ELISA, enzyme-linked immunosorbent assay; IHC, immunohistochemistry; IFN, interferon; IL, interleukin; n.d., not described; n-DBSS, neonatal dried-blood samples; PBMC, peripheral blood mononuclear cells; PCR, polymerase chain reaction; TNF, tumor necrosis factor; $\uparrow$, increased expression; $\downarrow$, decreased expression. 
Table 2. Main cytokines with altered levels in the VPA animal model of autism

\begin{tabular}{|c|c|c|c|c|c|c|c|c|}
\hline $\begin{array}{l}\text { Animal } \\
\text { used }\end{array}$ & $\begin{array}{l}\text { Dosage, } \\
\mathrm{mg} / \mathrm{kg}\end{array}$ & $\begin{array}{l}\text { Embryonic } \\
\text { day }\end{array}$ & $\begin{array}{l}\text { Administration } \\
\text { route }\end{array}$ & Source & Age & Outcome/cytokine expression & $\begin{array}{l}\text { Analysis } \\
\text { method }\end{array}$ & Ref. \\
\hline $\begin{array}{l}\mathrm{BALB} / \mathrm{c} \\
\text { mice }\end{array}$ & 600 & E11 & subcutaneous & dorsal hippocampus & P28 & $\uparrow \mathrm{IL}-1 \beta$ & PCR & 122 \\
\hline $\begin{array}{l}\mathrm{BALB} / \mathrm{c} \\
\text { mice }\end{array}$ & $\begin{array}{l}400 \\
600\end{array}$ & E12.5 & subcutaneous & spleen & $\begin{array}{l}8-10 \\
\text { weeks }\end{array}$ & $\begin{array}{l}\text { VPA did not induce an inflammatory } \\
\text { response, but showed an exacerbated } \\
\text { response to LPS challenge: } \\
\uparrow \text { IL- } 1 \beta \text {, IL- } 6 \text {, and TNF- } \alpha\end{array}$ & PCR & 109 \\
\hline $\begin{array}{l}\mathrm{BALB} / \mathrm{c} \\
\text { mice }\end{array}$ & $\begin{array}{l}400 \\
600\end{array}$ & E12.5 & subcutaneous & $\begin{array}{l}\text { hippocampus/ } \\
\text { cerebellum }\end{array}$ & $\begin{array}{l}8-10 \\
\text { weeks }\end{array}$ & $\begin{array}{l}\uparrow \text { IL- } 6 \text { and TNF- } \alpha \text { in VPA animals } \\
\text { exposed to LPS challenge }\end{array}$ & PCR & 109 \\
\hline $\begin{array}{l}\text { Wistar } \\
\text { rats }\end{array}$ & 600 & E12.5 & intraperitoneal & hippocampus & P40 & $\uparrow \mathrm{IL}-6, \uparrow \mathrm{IL}-1 \beta$ & ELISA & 123 \\
\hline $\begin{array}{l}\text { Wistar } \\
\text { rats }\end{array}$ & 800 & E12.5 & gavage & whole brain & $\mathrm{P} 21$ & $\uparrow$ IL-1 $\beta$, IL-6, TNF- $\alpha$ & ELISA & 124 \\
\hline
\end{tabular}

E, embryonic day; P, postnatal day; PCR, polymerase chain reaction; ELISA, enzyme-linked immunosorbent assay; $\uparrow$, increased expression.

$113]$. IL- $1 \beta$ stimulates the expression of inflammatory mediators and induces a Th17 response. It also plays an important role as a mediator of the anti-inflammatory response $[112,113]$.

Both elevations and reductions in IL- $1 \beta$ levels have been reported in ASD subjects. Increased levels of IL-1 $\beta$ were found in plasma $[114,115]$, serum $[116,117]$, and peripheral blood mononuclear cells (PBMC) [118-120]; decreased levels were described in neonatal dried-blood samples (n-DBSS) [121]. In the VPA animal model, IL-1 $\beta$ was increased in the hippocampus [122, 123], an LPSexposed hippocampus [109], and a whole-brain homogenate [124]. Increased levels of this cytokine are associated with increased stereotypy [120], one of the main characteristics of ASD.

\section{Interleukin 2}

IL-2 plays an important role, controlling the survival of immature and mature $T$ cells [125]. It is mainly secreted by $\mathrm{CD} 8+$ and $\mathrm{CD} 4+\mathrm{T}$ cells after recognition of the antigen and costimulators [111]. IL-2 is the most important cytokine for promoting the clonal expansion of antigen-activated $\mathrm{T}$ cells [126]. The only report concerning ASD was of a reduction of IL-2 levels in n-DBSS [121].

\section{Interleukin 4}

IL- 4 is the main cytokine of Th2 response and is primarily produced by T cells and mast cells. IL- 4 promotes the proliferation of $\mathrm{B}$ cells and cytotoxic $\mathrm{T}$ cells and stim- ulates IgG and IgE production [97]. It stimulates leukocyte recruitment and promotes the expression of adhesion molecules [127]. Increased levels of this cytokine have been associated with greater impairments in nonverbal communication [120]. In ASD subjects, reduced levels of IL-4 in n-DBSS [121] and elevated levels in amniotic fluid [128] have been reported.

\section{Interleukin 5}

IL-5 is a cytokine produced by T cells that acts as an activator of eosinophils [129]. IL-5 promotes eosinophil proliferation and maturation, stimulating IgA and IgM production [97]. In ASD patients, a decrease in IL-5 in n-DBSS [121] and an increase in plasma samples [115] have been described.

\section{Interleukin 6}

The main sources of IL- 6 are Th cells, macrophages, and fibroblasts. IL- 6 targets activated B cells and plasma cells, promoting the differentiation into plasma cells and the production of IgG [97]. IL-6 is also involved in the induction of a Th17 response and it has a dual profile, i.e., pro- and anti-inflammatory [112, 113]. Studies have demonstrated the essential involvement of IL-6 in triggering core symptoms related to the proinflammatory response in the autistic model of maternal immune activation (MIA) [130].

Increased levels of IL-6 are associated with increased stereotypy in ASD [120], impaired cognitive abilities, abnormal anxiety, and decreased social interactions [107]. 


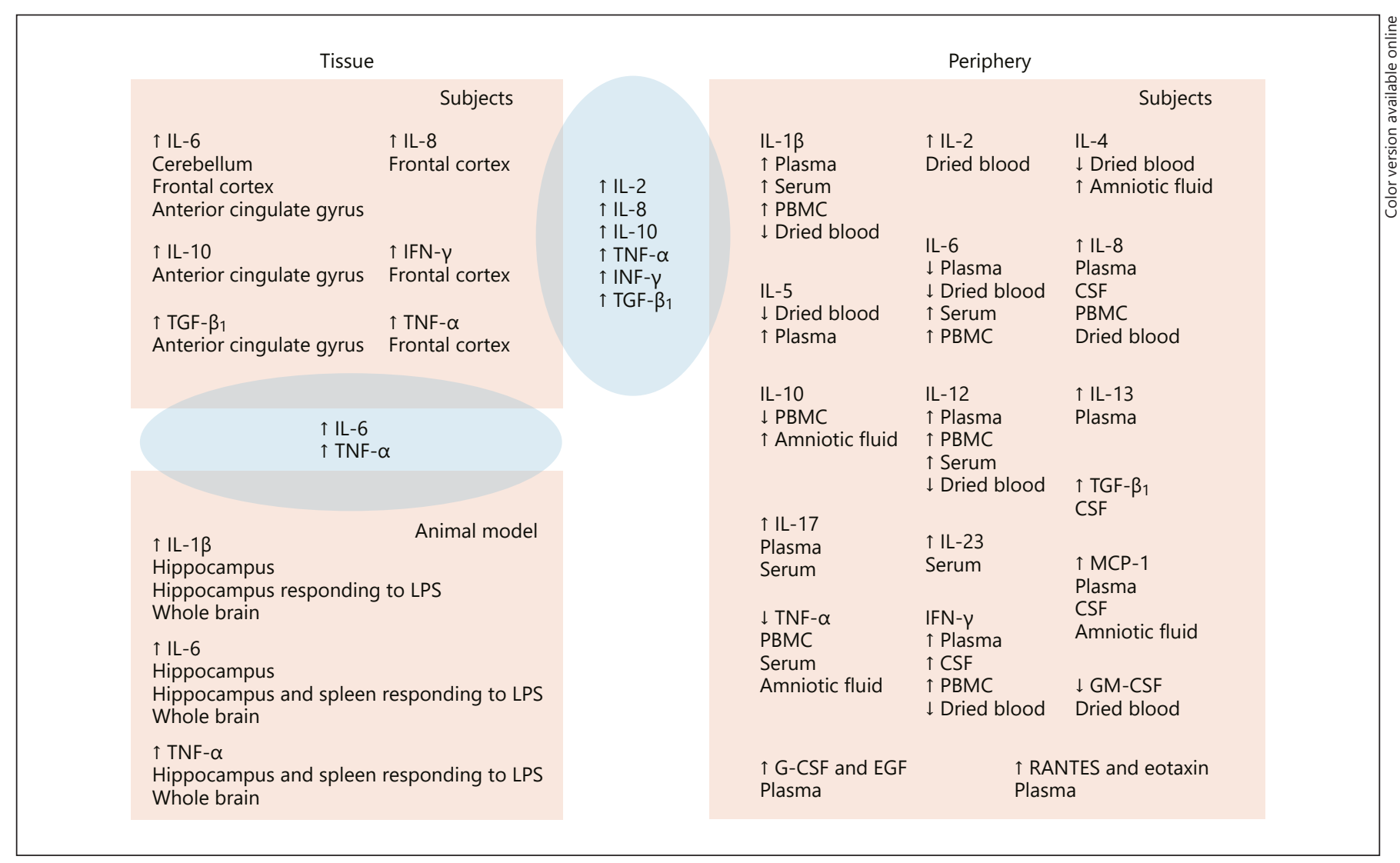

Fig. 2. Main results of cytokines altered in both ASD subjects and the VPA animal model. At the interface of the columns and rows are the findings shared by human subjects and the animal model from different biological sources. See Table 1 for abbreviations and references.

We reviewed the main findings about IL-6 levels in ASD: IL-6 is elevated in the brain tissue (cerebellum, frontal cortex, and anterior cingulate gyrus) [7, 131, 132], serum, and PBMC [116-120], but is reduced in plasma and n-DBSS $[114,121]$. In the VPA animal model of autism, higher levels of IL- 6 were reported in the hippocampus [123], the hippocampus and spleen after LPS challenge [109], and a whole-brain homogenate [124].

\section{Interleukin 8}

IL-8 is a chemoattractant cytokine produced mainly by macrophages that specifically targets neutrophils, promoting their activation [133]. So its major functions result from its chemotactic and proinflammatory activities [97]. Elevated levels of this cytokine are associated with increased hyperactivity, stereotypy, and lethargy [120]. Higher levels of IL-8 have been observed in the frontal cortex [132], plasma [115], CSF [134], PBMC [120], and n-DBSS [121] of ASD subjects.

Neuroimmune Alterations in Autism

Focusing on the VPA Model

\section{Interleukin 10}

This cytokine can be produced by several types of cells including DCs, macrophages, mast cells, NK cells, eosinophils, neutrophils, and B cells [135]. It is able to regulate the growth and/or differentiation of B cells, NK cells, cytotoxic T cells, Th cells, mast cells, granulocytes, DC, keratinocytes, and EC, exerting a primarily anti-inflammatory activity $[97,135]$. IL-10 is important to fine-tune the immune response against invading pathogens, maintaining the homeostatic state [135]. In ASD patients, increased levels were found in the anterior cingulate gyrus and the amniotic fluid $[128,134]$, and decreased levels were found in PBMCs [96].

\section{Interleukin 12}

IL-12 is produced by T cells and acts on naïve T cells and NK cells, activating them [97] and also inducing IFN- $\gamma$ production, which is critical for the induction of Th1 cells [136]. Plasma, PBMC, and serum of ASD sub- 
jects show higher levels of IL-12 [115, 117, 120] whereas n-DBSS show lower levels [121]. Increased IL-12 levels are associated with increased stereotypy and lethargy in ASD patients [120].

\section{Interleukin 13}

Similar to IL-4, IL-13 is involved in type 2 immunity and is produced by $\mathrm{T}$ cells. However, basophils, eosinophils, and NK cells can also produce IL-13 [137]. The only report concerning autistic patients showed increased plasma levels of IL-13 [115].

\section{Interleukin 17}

IL-17 plays an important role in the immunity against intra- and extracellular pathogens [138]. IL-17-producing cells, including NK cells and innate lymphoid cells, play crucial roles in inflammation-associated disease, such as infection, autoimmunity, and tumors [139]. The effector role of IL-17a at the onset of MIA-induced behavioral abnormalities in offspring has also been described, showing the important crosstalk between the neuroinflammatory state and behavioral manifestations [140]. Increase levels of IL-17 have been reported in the plasma and serum $[115,141]$ of patients with ASD.

\section{Interleukin 23}

Considered a proinflammatory cytokine essential for the differentiation of Th17 lymphocytes [142], IL-23 is produced by macrophages, DC, keratinocytes, and other antigen-presenting cells after the recognition of microorganisms [143]. IL-23 is critically involved in autoimmune disease responses [144]. In autistic patients, elevated IL-23 levels in serum samples have been reported [117].

\section{Tumor Necrosis Factor $\alpha$}

TNF- $\alpha$ is an endotoxin-induced serum factor promoting phagocyte cell activation [97], whose main targets and producers are macrophages. TNF- $\alpha$ is found at higher levels both in ASD patients (frontal cortex [132], PBMC $[96,118,119,145]$, serum [117], and amniotic fluid [128]) and in the VPA animal model of autism (in the hippocampus and spleen responding to LPS [109] and in wholebrain tissue [124]).

\section{Interferon $\gamma$}

IFN- $\gamma$ plays an important role in the host defense against intracellular pathogens. It is produced by NK T cells, CD8+ T cells, and CD4+ T cells, and its functions include supporting Th1 differentiation [146], macro- phage activation, and increasing neutrophil and monocyte function [97]. Patients with ASD have increased levels of IFN- $\gamma$ in the frontal cortex [132], plasma [147], CSF [134], and PBMC [96], and reduced levels in n-DBSS [121].

\section{Tumor Growth Factor $\beta$}

TGF- $\beta$ is primarily secreted by T cells and B cells, and acts in activated $\mathrm{T}$ and $\mathrm{B}$ cells. The major function of this cytokine is to inhibit hematopoiesis and $\mathrm{T}$ and $\mathrm{B}$ cell proliferation [97]. Higher levels of TGF- $\beta_{1}$ were reported in the anterior cingulate gyrus and CSF [134] of ASD subjects.

\section{Monocyte Chemoattractant Protein 1}

Monocyte chemoattractant protein 1 (MCP-1) or C-C chemokine ligand 2 (CCL2) signals to cells that contain the specific CCR2 receptor, stimulating their migration to sites where CCL2 is produced, and thereby facilitating the amplification of neuroinflammation [148]. Higher levels of MCP-1 have been observed in the plasma [149], CSF [134], and amniotic fluid [128] of autistic subjects. Increased levels in the plasma are associated with greater impairments in visual reception, fine motor skills, and expressive language [149].

\section{Granulocyte-Macrophage Colony-Stimulating Factor}

Granulocyte-macrophage colony-stimulating factor (GM-CSF) is produced by T cells, macrophages, and fibroblasts, and targets stem cells. Its major function is to stimulate the production of granulocytes, monocytes, and eosinophils [97]. Diminished levels of GM-CSF have been described in the n-DBSS of pediatric ASD subjects [121].

\section{Granulocyte Colony-Stimulating Factor}

The main sources of granulocyte colony-stimulating factor (G-CSF) are fibroblasts and EC, and its targets are stem cells in the bone marrow. G-CSF has a hematopoietic function and stimulates granulocyte production [97]. Higher levels of this cytokine have been observed in the plasma of autistic patients [114].

\section{Epidermal Growth Factor}

Epidermal growth factor (EGF) is a small chemoattractant peptide, produced by activated T cells, that is involved in wound-healing by attracting fibroblasts and epithelial cells [114]. Higher levels of this chemokine have been reported in plasma samples from autistic patients [114]. 


\section{RANTES}

Regulated on activation, normal $\mathrm{T}$ cell expressed and secreted (RANTES) chemokine or CCL5 is involved in immune cell transport to the inflammation site, promoting polarization towards a Th1 response [150]. Higher levels are associated with the increased severity of lethargy, stereotypy, and hyperactivity [149] in ASD patients.

\section{Eotaxin}

The CC chemokine eotaxin/CCL11 is known to bind to the receptor CCR3 on eosinophils and Th2-type lymphocytes [151]. Increased levels of eotaxin are associated with the increased severity of lethargy, stereotypy, and hyperactivity in ASD subjects [149].

\section{Final Considerations}

There is a high prevalence and growing incidence of ASD over the last few years. This has driven investments into public health and mobilized researchers and health professionals worldwide. There has been significant progress in ASD research since the disorder was first described, but, to date, its etiology remains unclear. An in- teresting hypothesis is that dysregulation of neuroimmune communication is involved in the onset of ASD. In this review, we summarized the main neuroimmune alterations found in both ASD subjects and the VPA animal model of autism. Notably, several changes in the VPA model indeed reflect the alterations found to occur in ASD patients (Fig. 2). Animal models that present evidence and construct validity, such as the VPA model, can be an effective tool for the investigation of pathways and tissue alterations involved in the pathogenesis of ASD.

\section{Acknowledgements}

This work was supported by development agencies: Conselho Nacional de Desenvolvimento Científico e Tecnológico (CNPq), Coordenação de Aperfeiçoamento de Pessoal de Nível Superior (Capes) e Instituto Nacional de Ciência e Tecnologia em NeuroImunoModulação (INCT-NIM). We would also like to thank online infographic maker, Mind the Graph (attribution share-alike 4.0 licensing) for the templates of schematic figures.

\section{Disclosure Statement}

The authors have no conflicts of interest.

\section{References}

1 Kanner L: Autistic disturbances of affective contact. Nerv Child 1943;2:217-250.

2 DSM-5 diagnostic classification; in: Diagnostic and Statistical Manual of Mental Disorders. American Psychiatric Association, 2013. DOI: 10.1176/appi.books.9780890425596.x00 DiagnosticClassification.

3 Huerta M, Lord C: Diagnostic evaluation of autism spectrum disorders. Pediatr Clin North Am 2012;103-111.

4 Gadia CA, Tuchman R, Rotta NT: Autismo e doenças invasivas de desenvolvimento. J Pediatr 2004;S83-S94.

5 Rapin I, Tuchman RF: Autism: definition, neurobiology, screening, diagnosis. Pediatr Clin North Am 2008;55:1129-1146.

6 Tonhajzerova I, Ondrejka I, Mestanik M, Mikolka P, Hrtanek I, Mestanikova A, et al: Inflammatory activity in autism spectrum disorder. Adv Exp Med Biol 2015;861:93-98.

7 Vargas DL, Nascimbene C, Krishnan C, Zimmerman AW, Pardo CA: Neuroglial activation and neuroinflammation in the brain of patients with autism. Ann Neurol 2005;57: 67-81.

8 Autism Spectrum Disorders Working Group of The Psychiatric Genomics Consortium: Meta-analysis of GWAS of over 16,000 indi- viduals with autism spectrum disorder highlights a novel locus at 10q24.32 and a significant overlap with schizophrenia. Mol Autism 2017;8:21.

9 Lintas C, Sacco R, Persico AM: Genome-wide expression studies in autism spectrum disorder, Rett syndrome, and Down syndrome. Neurobiol Dis 2012;45:57-68.

10 Skafidas E, Testa R, Zantomio D, Chana G, Everall IP, Pantelis C: Predicting the diagnosis of autism spectrum disorder using gene pathway analysis. Mol Psychiatry 2014;19: 504-510.

11 Christensen DL, Baio J, Braun KVN, Bilder D, Charles J, Constantino JN, et al: Prevalence and characteristics of autism spectrum disorder among children aged 8 years - Autism and Developmental Disabilities Monitoring Network, 11 Sites, United States, 2012. MMWR Surveill Summ 2016;65:1-23.

12 Smith V, Brown N: Prenatal valproate exposure and risk of autism spectrum disorders and childhood autism. Arch Dis Child Educ Pract Ed 2014;99:198.

13 Roullet FI, Lai JKY, Foster JA: In utero exposure to valproic acid and autism - a current review of clinical and animal studies. Neurotoxicol Teratol 2013;36:47-56.
14 Ranger P, Ellenbroek BA: Perinatal influences of valproate on brain and behaviour: an animal model for autism. Curr Top Behav Neurosci 2016;29:363-386.

15 Christianson AL, Chester N, Kromberg JGR Fetal valproate syndrome: clinical and neurodevelopmental features in two sibling pairs. Dev Med Child Neurol 1994;36:361-369.

16 Moore SJ, Turnpenny P, Quinn A, Glover S, Lloyd DJ, Montgomery $\mathrm{T}$, et al: A clinical study of 57 children with fetal anticonvulsant syndromes. J Med Genet 2000;37:489-497.

17 Williams G, King J, Cunningham M, Stephan M, Kerr B, Hersh JH: Fetal valproate syndrome and autism: additional evidence of an association. Dev Med Child Neurol 2001;43:202-206.

18 Williams PG, Hersh JH: A male with fetal valproate syndrome and autism. Dev Med Child Neurol 1997;39:632-634.

19 Bambini-Junior V, Rodrigues L, Behr GA, Moreira JCF, Riesgo R, Gottfried C: Animal model of autism induced by prenatal exposure to valproate: behavioral changes and liver parameters. Brain Res 2011;1408:8-16.

20 Schneider T, Przewłocki R: Behavioral alterations in rats prenatally exposed to valproic acid: animal model of autism. Neuropsychopharmacology 2005;30:80-89.
Neuroimmune Alterations in Autism

Focusing on the VPA Model
Neuroimmunomodulation 2018;25:285-299 
21 Schneider T, Roman A, Basta-Kaim A, Kubera M, Budziszewska B, Schneider K, et al: Gender-specific behavioral and immunological alterations in an animal model of autism induced by prenatal exposure to valproic acid. Psychoneuroendocrinology 2008;33:728740.

22 Roullet FI, Wollaston L, Decatanzaro D, Foster JA: Behavioral and molecular changes in the mouse in response to prenatal exposure to the anti-epileptic drug valproic acid. Neuroscience 2010;170:514-522.

23 Baronio D, Castro K, Gonchoroski T, de Melo GM, Nunes GDF, Bambini-Junior V, et al: Effects of an H3R antagonist on the animal model of autism induced by prenatal exposure to valproic acid. PLoS One 2015; 10:e0116363.

24 Favre MR, Barkat TR, Lamendola D, Khazen G, Markram H, Markram K: General developmental health in the VPA-rat model of autism. Front Behav Neurosci 2013;7:88

25 Kataoka S, Takuma K, Hara Y, Maeda Y, Ago Y, Matsuda T: Autism-like behaviours with transient histone hyperacetylation in mice treated prenatally with valproic acid. Int J Neuropsychopharmacol 2013;16:91-103.

26 Zhubi A, Cook EH, Guidotti A, Grayson DR: Epigenetic mechanisms in autism spectrum disorder. Int Rev Neurobiol 2014;115:203244.

27 Uher R: Gene-environment interactions in severe mental illness. Front Psychiatry 2014; 5:48.

28 Misztak P, Pańczyszyn-Trzewik P, SowaKućma M: Histone deacetylases (HDACs) as therapeutic target for depressive disorders. Pharmacol Reports 2018;70:398-408.

29 Koprinarova M, Schnekenburger M, Diederich M: Role of histone acetylation in cell cycle regulation. Curr Top Med Chem 2015;16: 732-744.

30 Nadal S, Raj R, Mohammed S, Davis BG: Synthetic post-translational modification of histones. Curr Opin Chem Biol 2018;45:35-47.

$31 \mathrm{Hu} \mathrm{Y}$, Suliman BA: Roles of HDACs in the responses of innate immune cells and as targets in inflammatory diseases. Adv Exp Med Biol 2017;1024:91-110.

32 Magner WJ, Kazim AL, Stewart C, Romano MA, Catalano G, Grande C, et al: Activation of MHC class I, II, and CD40 gene expression by histone deacetylase inhibitors. J Immunol 2000;165:7017-24.

33 Kroesen M, Gielen PR, Brok IC, Armandari I, Hoogerbrugge PM, Adema GJ: HDAC inhibitors and immunotherapy; a double-edged sword? Oncotarget 2014;5:6558-6572.

34 Kawanai T, Ago Y, Watanabe R, Inoue A, Taruta $\mathrm{A}$, Onaka $\mathrm{Y}$, et al: prenatal exposure to histone deacetylase inhibitors affects gene expression of autism-related molecules and delays neuronal maturation. Neurochem Res 2016;41:2574-2584.
35 Marchetto MC, Belinson H, Tian Y, Freitas BC, Fu C, Vadodaria K, et al: Altered proliferation and networks in neural cells derived from idiopathic autistic individuals. Mol Psychiatry 2017;22:820-835.

36 Kazlauskas N, Campolongo M, Lucchina L, Zappala C, Depino AM: Postnatal behavioral and inflammatory alterations in female pups prenatally exposed to valproic acid. Psychoneuroendocrinology 2016;72:11-21.

37 Lee HJ, Dreyfus C, DiCicco-Bloom E: Valproic acid stimulates proliferation of glial precursors during cortical gliogenesis in developing rat. Dev Neurobiol 2016;76:780-798.

38 Perisic T, Zimmermann N, Kirmeier T, Asmus M, Tuorto F, Uhr M, et al: Valproate and amitriptyline exert common and divergent influences on global and gene promoter-specific chromatin modifications in rat primary astrocytes. Neuropsychopharmacology 2010; 35:792-805.

39 Göttlicher M, Minucci S, Zhu P, Krämer OH, Schimpf A, Giavara S, et al: Valproic acid defines a novel class of HDAC inhibitors inducing differentiation of transformed cells. EMBO J 2001;20:6969-6978.

40 Louveau A, Smirnov I, Keyes TJ, Eccles JD, Rouhani SJ, Peske JD, et al: Structural and functional features of central nervous system lymphatic vessels. Nature 2015;523:337-341.

41 Louveau A, Harris TH, Kipnis J: Revisiting the mechanisms of CNS immune privilege. Trends Immunol 2015;36:569-577.

42 Daneman R, Prat A: The blood-brain barrier. Cold Spring Harb Perspect Biol 2015; 7:a020412.

43 Wang Y, Rattner A, Zhou Y, Williams J, Smallwood PM, Nathans J: Norrin/Frizzled4 signaling in retinal vascular development and blood brain barrier plasticity. Cell 2012;151: 1332-1344.

44 Zhou Y, Nathans J: Gpr124 controls CNS angiogenesis and blood-brain barrier integrity by promoting ligand-specific canonical Wnt signaling. Dev Cell 2014;31:248-256.

45 Zhou Y, Wang Y, Tischfield M, Williams J, Smallwood PM, Rattner A, et al: Canonical WNT signaling components in vascular development and barrier formation. J Clin Invest 2014;124:3825-3846.

46 Hagan N, Ben-Zvi A: The molecular, cellular, and morphological components of bloodbrain barrier development during embryogenesis. Semin Cell Dev Biol 2015;38:7-15.

47 Zhao Z, Nelson AR, Betsholtz C, Zlokovic B $\mathrm{V}$ : establishment and dysfunction of the blood-brain barrier. Cell 2015;163:10641078 .

48 Daneman R, Zhou L, Kebede AA, Barres BA: Pericytes are required for blood-brain barrier integrity during embryogenesis. Nature 2010; 468:562-566.

49 Bell RD, Winkler EA, Sagare AP, Singh I, LaRue B, Deane R, et al: Pericytes control key neurovascular functions and neuronal phenotype in the adult brain and during brain aging. Neuron 2010;68:409-427.
50 Li Q, Barres BA: Microglia and macrophages in brain homeostasis and disease. Nat Rev Immunol 2018; 18:225-242.

51 Butovsky O, Jedrychowski MP, Moore CS, Cialic R, Lanser AJ, Gabriely G, et al: Identification of a unique TGF- $\beta$-dependent molecular and functional signature in microglia. Nat Neurosci 2014;17:131-143.

52 Bohlen CJ, Bennett FC, Tucker AF, Collins HY, Mulinyawe SB, Barres BA: Diverse requirements for microglial survival, specification, and function revealed by defined-medium cultures. Neuron 2017;94:759-773.e8.

53 Kreutzberg GW: Microglia: a sensor for pathological events in the CNS. Trends Neurosci 1996;19:312-318.

54 Raivich G, Banati R: Brain microglia and blood-derived macrophages: molecular profiles and functional roles in multiple sclerosis and animal models of autoimmune demyelinating disease. Brain Res Rev 2004;46:261-281.

55 Nimmerjahn A, Kirchhoff F, Helmchen F: Resting microglial cells are highly dynamic surveillants of brain parenchyma in vivo. Science 2005;308:1314-1318.

56 Wake H, Moorhouse AJ, Jinno S, Kohsaka S, Nabekura J: Resting microglia directly monitor the functional state of synapses in vivo and determine the fate of ischemic terminals. J Neurosci 2009;29:3974-3980.

57 Olson JK, Miller SD: Microglia initiate central nervous system innate and adaptive immune responses through multiple TLRs. J Immunol 2004;173:3916-3924

58 Buttgereit A, Lelios I, Yu X, Vrohlings M, Krakoski NR, Gautier EL, et al: Sall1 is a transcriptional regulator defining microglia identity and function. Nat Immunol 2016;17: 1397-1406.

59 Parisi C, Napoli G, Pelegrin P, Volonté C: M1 and $\mathrm{m} 2$ functional imprinting of primary microglia: role of $\mathrm{P} 2 \mathrm{X} 7$ activation and miR125b. Mediators Inflamm 2016;2016:2989548.

60 Hanisch U-K, Prinz M, Angstwurm K, Hausler KG, Kann O, Kettenmann H, et al: The protein tyrosine kinase inhibitor AG126 prevents the massive microglial cytokine induction by pneumococcal cell walls. Eur J Immunol 2001;31:2104-2115.

61 Häusler KG, Prinz M, Nolte C, Weber JR, Schumann RR, Kettenmann H, et al: Interferon-gamma differentially modulates the release of cytokines and chemokines in lipopolysaccharide- and pneumococcal cell wallstimulated mousemicroglia and macrophages. Eur J Neurosci 2002;16:2113-2122.

62 Škuljec J, Sun H, Pul R, Bénardais K, Ragancokova D, Moharregh-Khiabani D, et al: CCL5 induces a pro-inflammatory profile in microglia in vitro. Cell Immunol 2011;270: 164-171.

63 Zarruk JG, Greenhalgh AD, David S: Microglia and macrophages differ in their inflammatory profile after permanent brain ischemia. Exp Neurol 2018;301:120-132. 
$64 \mathrm{Hu}$ X, Leak RK, Shi Y, Suenaga J, Gao Y, Zheng $P$, et al: Microglial and macrophage polarization - new prospects for brain repair. Nat Rev Neurol 2015;11:56-64.

65 Hanisch U-K, Kettenmann H: Microglia: active sensor and versatile effector cells in the normal and pathologic brain. Nat Neurosci 2007;10:1387-1394.

66 Friedman BA, Srinivasan K, Ayalon G, Meilandt WJ, Lin H, Huntley MA, et al: Diverse brain myeloid expression profiles reveal distinct microglial activation states and aspects of Alzheimer's disease not evident in mouse models. Cell Rep 2018;22:832-847.

67 Koyama R, Ikegaya Y: Microglia in the pathogenesis of autism spectrum disorders. Neurosci Res 2015;100:1-5.

68 Hansen DV, Hanson JE, Sheng M: Microglia in Alzheimer's disease. J Cell Biol 2018;217: 459-472.

69 Lucchinetti CF, Popescu BFG, Bunyan RF, Moll NM, Roemer SF, Lassmann H, et al: Inflammatory cortical demyelination in early multiple sclerosis. N Engl J Med 2011;365: 2188-2197.

70 Antonietta Ajmone-Cat M, Mancini M, De Simone R, Cilli P, Minghetti L: Microglial polarization and plasticity: evidence from organotypic hippocampal slice cultures. Glia 2013;61:1698-1711.

71 Serhan CN, Savill J: Resolution of inflammation: the beginning programs the end. Nat Immunol 2005;6:1191-1197.

72 Herz J, Filiano AJ, Smith A, Yogev N, Kipnis J: Myeloid cells in the central nervous system. Immunity 2017;46:943-956.

73 Serrats J, Schiltz JC, García-Bueno B, van Rooijen N, Reyes TM, Sawchenko PE: Dual roles for perivascular macrophages in immune-to-brain signaling. Neuron 2010;65: 94-106.

74 Williams K, Alvarez X, Lackner AA: Central nervous system perivascular cells are immunoregulatory cells that connect the CNS with the peripheral immune system. Glia 2001;36: 156-164.

75 He H, Mack JJ, Güç E, Warren CM, Squadrito ML, Kilarski WW, et al: Perivascular macrophages limit permeability. Arterioscler Thromb Vasc Biol 2016;36:2203-2212.

76 Shechter R, London A, Schwartz M: Orchestrated leukocyte recruitment to immuneprivileged sites: absolute barriers versus educational gates. Nat Rev Immunol 2013;13: 206-218.

77 Quintana E, Fernández A, Velasco P, de Andrés B, Liste I, Sancho D, et al: DNGR-1+ dendritic cells are located in meningeal membrane and choroid plexus of the noninjured brain. Glia 2015;63:2231-2248.

78 Meeker RB, Williams K, Killebrew DA, Hudson LC: Cell trafficking through the choroid plexus. Cell Adh Migr 2012;6:390-396.
79 Mendez-Gomez HR, Galera-Prat A, Meyers C, Chen W, Carrion-Vazquez M, Muzyczka $\mathrm{N}$ : Crossing the blood-cerebrospinal fluid barrier in the mouse choroid plexus with an engineered receptor/ligand system. Mol Ther 2015;23:S65

80 Kierdorf K, Prinz M, Gomez Perdiguero E: Development and function of tissue resident macrophages in mice. Semin Immunol 2015; 27:369-378.

81 Roth TL, Nayak D, Atanasijevic T, Koretsky AP, Latour LL, McGavern DB: Transcranial amelioration of inflammation and cell death after brain injury. Nature 2014;505:223-228.

82 Mildner A, Mack M, Schmidt H, Brück W, Djukic M, Zabel MD, et al: CCR2+Ly-6x monocytes are crucial for the effector phase of autoimmunity in the central nervous system. Brain 2009;132:2487-2500.

83 Dong H, Zhang X, Qian Y: Mast cells and neuroinflammation. Med Sci Monit Basic Res 2014;20:200-206.

84 Prinz M, Priller J: The role of peripheral immune cells in the CNS in steady state and disease. Nat Neurosci 2017;20:136-144.

85 Nau R, Zettl U, Gerber J, Trostdorf F, Michel $\mathrm{U}$, Böttcher T, et al: Granulocytes in the subarachnoid space of humans and rabbits with bacterial meningitis undergo apoptosis and are eliminated by macrophages. Acta Neuropathol 1998;96:472-480.

86 McMenamin PG, Wealthall RJ, Deverall M, Cooper SJ, Griffin B: Macrophages and dendritic cells in the rat meninges and choroid plexus: three-dimensional localisation by environmental scanning electron microscopy and confocal microscopy. Cell Tissue Res 2003;313:259-269.

87 Chinnery HR, Ruitenberg MJ, McMenamin PG: Novel characterization of monocyte-derived cell populations in the meninges and choroid plexus and their rates of replenishment in bone marrow chimeric mice. J Neuropathol Exp Neurol 2010;69:896-909.

88 Anandasabapathy N, Victora GD, Meredith M, Feder R, Dong B, Kluger C, et al: Flt3L controls the development of radiosensitive dendritic cells in the meninges and choroid plexus of the steady-state mouse brain. J Exp Med 2011;208:1695-1705.

89 Prendergast CT, Anderton SM: Immune cell entry to central nervous system - current understanding and prospective therapeutic targets. Endocr Metab Immune Disord Drug Targets 2009;9:315-327.

90 Fabis MJ, Phares TW, Kean RB, Koprowski H, Hooper DC: Blood-brain barrier changes and cell invasion differ between therapeutic immune clearance of neurotrophic virus and CNS autoimmunity. Proc Natl Acad Sci USA 2008;105:15511-15516.

91 Arima Y, Kamimura D, Sabharwal L, Yamada M, Bando H, Ogura H, et al: Regulation of immune cell infiltration into the CNS by regional neural inputs explained by the gate theory. Mediators Inflamm 2013;2013:898165.
92 Dendrou CA, Fugger L, Friese MA: Immunopathology of multiple sclerosis. Nat Rev Immunol 2015;15:545-558.

93 da Fonseca ACC, Matias D, Garcia C, Amaral R, Geraldo LH, Freitas C, et al: The impact of microglial activation on blood-brain barrier in brain diseases. Front Cell Neurosci 2014;8:362.

94 Phares TW, Kean RB, Mikheeva T, Hooper DC: Regional differences in blood-brain barrier permeability changes and inflammation in the apathogenic clearance of virus from the central nervous system. J Immunol 2006;114:1761-1765.

95 Bilbo SD, Block CL, Bolton JL, Hanamsagar $\mathrm{R}$, Tran PK: Beyond infection - maternal immune activation by environmental factors, microglial development, and relevance for autism spectrum disorders. Exp Neurol 2018;299:241-251.

96 Ashwood P, Wills S, Van de Water J: The immune response in autism: a new frontier for autism research. J Leukoc Biol 2006;80: $1-15$.

97 Turner MD, Nedjai B, Hurst T, Pennington DJ: Cytokines and chemokines: at the crossroads of cell signalling and inflammatory disease. Biochim Biophys Acta 2014;1843: 2563-2582.

98 Masi A, Glozier N, Dale R, Guastella AJ: The immune system, cytokines, and biomarkers in autism spectrum disorder. Neurosci Bull 2017;33:194-204

99 Ramesh G, MacLean AG, Philipp MT: Cytokines and chemokines at the crossroads of neuroinflammation, neurodegeneration, and neuropathic pain. Mediators Inflamm 2013;2013:480739.

100 Biber K, Vinet J, Boddeke HWGM: Neuronmicroglia signaling: chemokines as versatile messengers. J Neuroimmunol 2008;198:6974.

101 Réaux-Le Goazigo A, Van Steenwinckel J, Rostène W, Mélik Parsadaniantz S: Current status of chemokines in the adult CNS. Prog Neurobiol 2013;104:67-92.

102 Janeway CA Jr, Travers P, Walport M, Shlomchik MJ (eds): Immunobiology: The Immune System in Health and Disease, ed 5. New York, Garland Science, 2001.

103 Metz DP, Bottomly K: Function and regulation of memory CD4 T cells. Immunol Res 1999; 19:127-141.

104 Amedei A, Prisco D, D’Elios M: Multiple sclerosis: the role of cytokines in pathogenesis and in therapies. Int J Mol Sci 2012;13: 13438-13460.

105 Vijayakumar NT, Judy MV: Autism spectrum disorders: integration of the genome, transcriptome and the environment. J Neurol Sci 2016;364:167-176.

106 Erta M, Giralt M, Esposito FL, FernandezGayol O, Hidalgo J: Astrocytic IL-6 mediates locomotor activity, exploration, anxiety, learning and social behavior. Horm Behav 2015;73:64-74.
Neuroimmune Alterations in Autism

Focusing on the VPA Model
Neuroimmunomodulation 2018:25:285-299 
107 Wei H, Chadman KK, McCloskey DP, Sheikh AM, Malik M, Brown WT, et al: Brain IL-6 elevation causes neuronal circuitry imbalances and mediates autism-like behaviors. Biochim Biophys Acta 2012;1822: 831-842.

108 Bluthé RM, Michaud B, Poli V, Dantzer R: Role of IL-6 in cytokine-induced sickness behavior: a study with IL-6 deficient mice. Physiol Behav 2000;70:367-73.

109 Lucchina L, Depino AM: Altered peripheral and central inflammatory responses in a mouse model of autism. Autism Res 2013;7: 273-289.

110 Gottfried C, Bambini-Junior V, Francis F, Riesgo R, Savino W: the impact of neuroimmune alterations in autism spectrum disorder. Front Psychiatry 2015;6:121.

111 Musolino C, Allegra A, Innao V, Allegra AG, Pioggia G, Gangemi S: Inflammatory and anti-inflammatory equilibrium, proliferative and antiproliferative balance: the role of cytokines in multiple myeloma. Mediators Inflamm 2017;2017:1852517.

112 Dinarello CA: Immunological and inflammatory functions of the interleukin-1 family. Annu Rev Immunol 2009;27:519-550.

113 Gray SM, Bloch MH: Systematic review of proinflammatory cytokines in obsessivecompulsive disorder. Curr Psychiatry Rep 2012;14:220-228.

114 Manzardo AM, Henkhaus R, Dhillon S, Butler MG: Plasma cytokine levels in children with autistic disorder and unrelated siblings. Int J Dev Neurosci 2012;30:121-127.

115 Suzuki K, Matsuzaki H, Iwata K, Kameno Y, Shimmura C, Kawai S, et al: Plasma cytokine profiles in subjects with high-functioning autism spectrum disorders. PLoS One 2011; 6:1-6.

116 Emanuele E, Orsi P, Boso M, Broglia D, Brondino N, Barale F, et al: Low-grade endotoxemia in patients with severe autism. Neurosci Lett 2010;471:162-165.

117 Ricci S, Businaro R, Ippoliti F, Lo Vasco VR, Massoni F, Onofri E, et al: Altered cytokine and BDNF levels in autism spectrum disorder. Neurotox Res 2013;24:491-501.

118 Enstrom AM, Onore CE, Van de Water JA, Ashwood P: Differential monocyte responses to TLR ligands in children with autism spectrum disorders. Brain Behav Immun 2010;24:64-71.

119 Jyonouchi H, Sun S, Le H: Proinflammatory and regulatory cytokine production associated with innate and adaptive immune responses in children with autism spectrum disorders and developmental regression. J Neuroimmunol 2001;120:170-179.

120 Ashwood P, Krakowiak P, Hertz-Picciotto I, Hansen R, Pessah I, Van de Water J: Elevated plasma cytokines in autism spectrum disorders provide evidence of immune dysfunction and are associated with impaired behavioral outcome. Brain Behav Immun 2011;25:40-45.
121 Abdallah MW, Larsen N, Mortensen EL, Atladóttir HÓ, Nørgaard-Pedersen B, Bonefeld-Jørgensen EC, et al: Neonatal levels of cytokines and risk of autism spectrum disorders: an exploratory register-based historic birth cohort study utilizing the Danish Newborn Screening Biobank. J Neuroimmunol 2012;252:75-82.

122 Theije CGM, Wu J, Koelink PJ, Korte-Bouws GAH, Borre Y, Kas MJH, et al: Autisticlike behavioural and neurochemical changes in a mouse model of food allergy. Behav Brain Res 2014;261:265-274.

123 Wu H, Wang X, Gao J, Liang S, Hao Y, Sun C, et al: Fingolimod (FTY720) attenuates social deficits, learning and memory impairments, neuronal loss and neuroinflammation in the rat model of autism. Life Sci 2017; 173:43-54.

124 Hegazy HG, Ali EHA, Elgoly AHM: Interplay between pro-inflammatory cytokines and brain oxidative stress biomarkers: evidence of parallels between butyl paraben intoxication and the valproic acid brain physiopathology in autism rat model. Cytokine 2015;71:173-180.

125 Kelly E, Won A, Refaeli Y, Van Parijs L: IL-2 and related cytokines can promote $\mathrm{T}$ cell survival by activating AKT. J Immunol 2002; 168:597-603.

126 Malek TR: The main function of IL-2 is to promote the development of $\mathrm{T}$ regulatory cells. J Leukoc Biol 2003;74:961-965.

127 Fukuda T, Fukushima Y, Numao T, Ando N, Arima M, Nakajima H, et al: Role of interleukin-4 and vascular cell adhesion molecule-1 in selective eosinophil migration into the airways in allergic asthma. Am J Respir Cell Mol Biol 1996;14:84-94.

128 Abdallah MW, Larsen N, Grove J, Nørgaard-Pedersen B, Thorsen P, Mortensen EL, et al: Amniotic fluid inflammatory cytokines: potential markers of immunologic dysfunction in autism spectrum disorders. World J Biol Psychiatry 2013;528-538.

129 Greenfeder S, Umland SP, Cuss FM, Chapman RW, Egan RW: Th2 cytokines and asthma. The role of interleukin-5 in allergic eosinophilic disease. Respir Res 2001;2:71-79.

130 Smith SEP, Li J, Garbett K, Mirnics K, Patterson PH: Maternal immune activation alters fetal brain development through interleukin-6. J Neurosci 2007;27:10695-10702.

131 Wei H, Zou H, Sheikh AM, Malik M, Dobkin C, Brown WT, et al: IL-6 is increased in the cerebellum of autistic brain and alters neural cell adhesion, migration and synaptic formation. J Neuroinflamm 2011;8:1-10.

132 Li X, Chauhan A, Sheikh AM, Patil S, Chauhan V, Li XM, et al: Elevated immune response in the brain of autistic patients. J Neuroimmunol 2009;207:111-116.

133 Bickel M: The role of interleukin-8 in inflammation and mechanisms of regulation. J Periodontol 1993;64:456-460.
134 Vargas DL, Nascimbene C, Krishnan C, Zimmerman AW, Pardo CA: Neuroglial activation and neuroinflammation in the brain of patients with autism. Ann Neurol 2005; 57:67-81.

135 Ma X, Yan W, Zheng H, Du Q, Zhang L, Ban $\mathrm{Y}$, et al: Regulation of IL-10 and IL-12 production and function in macrophages and dendritic cells. F1000Res 2015;4:pii F1000.

136 Gee K, Guzzo C, Che Mat NF, Ma W, Kumar A: The IL-12 family of cytokines in infection, inflammation and autoimmune disorders. Inflamm Allergy Drug Targets 2009;8:4052.

137 Bao K, Reinhardt RL: The differential expression of IL-4 and IL-13 and its impact on type-2 immunity. Cytokine 2015;75:25-37.

138 Kuwabara T, Ishikawa F, Kondo M, Kakiuchi T: The role of IL-17 and related cytokines in inflammatory autoimmune diseases. Mediators Inflamm 2017;2017:1-11.

139 Zhong F, Cui D, Tao H, Du H, Xing C: IL-17A-producing $\mathrm{T}$ cells and associated cytokines are involved in the progression of gastric cancer. Oncol Rep 2015;34:23652374.

140 Choi GB, Yim YS, Wong H, Kim S, Kim H, Kim S V, et al: The maternal interleukin-17a pathway in mice promotes autism-like phenotypes in offspring. Science 2016;351:933939.

141 AL-Ayadhi LY, Mostafa GA: Elevated serum levels of interleukin-17A in children with autism. J Neuroinflamm 2012;9:595.

142 Toussirot E: The IL23/Th17 pathway as a therapeutic target in chronic inflammatory diseases. Inflamm Allergy Drug Targets 2012;11:159-68.

143 Fischer K, Przepiera-Będzak H, Sawicki M, Walecka A, Brzosko I, Brzosko M: Serum interleukin-23 in Polish patients with systemic lupus erythematosus: association with lupus nephritis, obesity, and peripheral vascular disease. Mediators Inflamm 2017;2017: 9401432.

144 Ziblat A, Nuñez SY, Raffo Iraolagoitia XL, Spallanzani RG, Torres NI, Sierra JM, et al: Interleukin (IL)- 23 stimulates IFN- $\gamma$ secretion by CD $56^{\text {bright }}$ natural killer cells and enhances IL-18-driven dendritic cell activation. Front Immunol 2018;8:1959.

145 Jyonouchi $\mathrm{H}$, Sun S, Itokazu N: Innate immunity associated with inflammatory responses and cytokine production against common dietary proteins in patients with autism spectrum disorder. Neuropsychobiology 2002;46:76-84.

146 Mah AY, Cooper MA: Metabolic regulation of natural killer cell IFN- $\gamma$ production. Crit Rev Immunol 2016;36:131-147.

147 Tostes MHFS, Teixeira HC, Gattaz WF, Brandão MAF, Raposo NRB: Altered neurotrophin, neuropeptide, cytokines and nitric oxide levels in autism. Pharmacopsychiatry 2012;45:241-243. 
148 Gutiérrez IL, González-Prieto M, GarcíaBueno B, Caso JR, Feinstein DL, Madrigal JLM: CCL2 induces the production of $\beta 2$ adrenergic receptors and modifies astrocytic responses to noradrenaline. Mol Neurobiol 2018;1-14.

149 Ashwood P, Krakowiak P, Hertz-Picciotto I, Hansen R, Pessah IN, Van de Water J: Associations of impaired behaviors with elevated plasma chemokines in autism spectrum disorders. J Neuroimmunol 2011;232: 196-199.
150 Fichna M, Żurawek M, Budny B, Komarowska $\mathrm{H}$, Niechciał E, Fichna P, et al: Elevated serum RANTES chemokine in autoimmune Addison's disease. Polish Arch Intern Med 2018;128:216-221.

151 Cheng SS, Lukacs NW, Kunkel SL: Eotaxin/ CCL11 suppresses IL-8/CXCL8 secretion from human dermal microvascular endothelial cells. J Immunol 2002; 168:28872894.

152 Ahmad SF, Zoheir KMA, Ansari MA, Nadeem A, Bakheet SA, AL-Ayadhi LY, et al: Dysregulation of Th1, Th2, Th17, and T regulatory cell-related transcription factor signaling in children with autism. Mol Neurobiol 2017;54:4390-4400.
153 Ashwood P, Anthony A, Torrente F, Wakefield AJ: Spontaneous mucosal lymphocyte cytokine profiles in children with autism and gastrointestinal symptoms: mucosal immune activation and reduced counter regulatory interleukin-10. J Clin Immunol 2004; 24:664-673.

154 Enstrom AM, Onore CE, Van de Water JA, Ashwood P: Differential monocyte responses to TLR ligands in children with autism spectrum disorders. Brain Behav Immun 2010;24:64-71. 